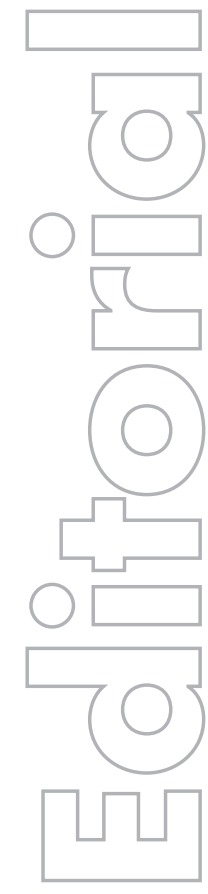

\section{revista}

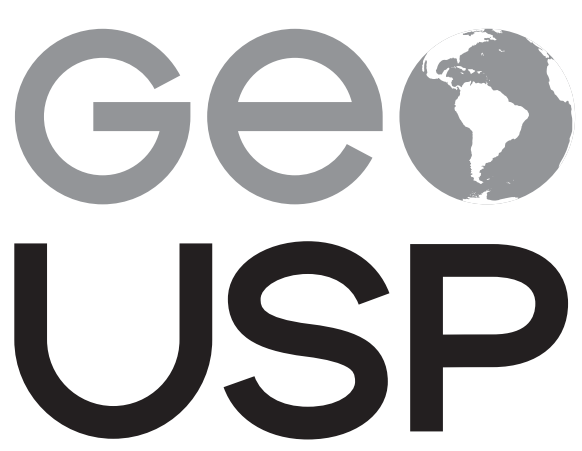

espaço e tempo

Volume 18, no 1 (2014)

\title{
Atualização da Geousp na plataforma digital
}

revista Geousp tem 18 anos de história. Nasceu como
periódico impresso, em 1997, e assim permaneceu até
o ano de 2009, com 27 números publicados, passando, desde então, a ser editada na plataforma digital Open Journal Systems (OJS). Neste primeiro número de 2014, a Geousp vem a público com um conjunto de mudanças que se fizeram necessárias para atualizá-la conforme as alterações que a plataforma veio sofrendo.

Dando continuidade à construção coletiva que caracteriza esta revista dos programas de pós-graduação em geografia humana e geografia física, buscamos consolidar o processo editorial por meio de maior participação docente na estrutura da Geousp, assim como de profissionais especializados em revisão e diagramação de textos e também em edição em plataforma digital. Vale mencionar aqui o grupo de docentes que aceitaram o desafio e se engajaram no novo projeto da revista: Rodrigo Ramos Hospodar Felippe Valverde, como editor assistente, e os editores de seção que cuidam do processo editorial nos subcampos da disciplina geográfica em que são especializados: Fábio Betioli Contel, Fernanda Padovesi Fonseca, Manoel Fernandes de Sousa Neto, Marta Inez Medeiros Marques, Maria Elisa Siqueira Silva e Cleide Rodrigues.

Para atender às novas práticas de pesquisa e leitura de artigos em periódicos, mudou também o projeto gráfico, e houve adequações técnicas necessárias à publicação de artigos científicos em plataforma eletrônica, mudança de periodicidade - de semestral para quadrimestral - e ampliação do quadro de pareceristas e do conselho científico, ainda em curso.

Ressaltamos que a Geousp agora está no Portal de Revistas da USP, contando com a assessoria técnica oferecida pelo Sistema Integrado de Bibliotecas da Universidade de São Paulo (SIBi-USP), nomeadamente na pessoa de André Serradas, cujo suporte diligente tem sido fundamental nesse con- 
junto de transformações, que dá aos artigos publicados mais segurança, visibilidade e acesso. Em breve, todos os artigos da Geousp passarão a ter Digital Object Identifier (DOI).

Não menos importante que todas essas mudanças é a implementação de novas políticas editoriais para a Geousp, no sentido de promover e ampliar a produção científica em geografia. Nessa perspectiva, uma primeira proposta é a criação da seção Ensaios, reservada a reflexões de pensadores da geografia brasileira e internacional: neste número, inaugura a seção o ensaio do Prof. Dr. Antonio Carlos Robert de Moraes.

Convidamos, assim, os leitores a apreciarem o primeiro número do volume 18 da Geousp, que, além do mencionado ensaio, traz 11 artigos inéditos, duas notas de pesquisa de campo e duas notícias de encontros.

Ricardo Mendes Antas Jr. Editor

Artigo disponível em:

http://www.revistas.usp.br/geousp/article/view/81071

\section{revista}
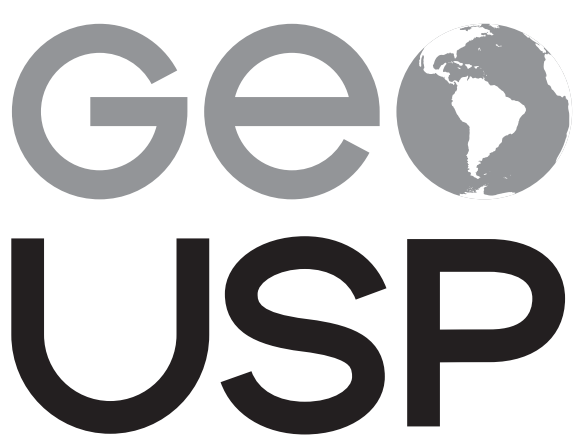

espaço e tempo

Volume 18, no 1 (2014) 